\title{
College Libraries with Dual Roles
}

TN THE fall of 1938 the American Asso1 ciation of University Professors completed an inquiry concerning governmental organization of higher education. ${ }^{1}$ It found that "the typical college and university does not have a definite plan in operation for facilitating exchange of opinion between the faculty and the trustees or regents" 2 but that there is a "trend toward selfgovernment by faculties." 3

In 1937 the University of New Hampshire adopted a new constitution which organized the faculty as a legislative body. ${ }^{4}$ Soon thereafter, the College of Education of Ohio State University reorganized its administration to give the faculty a share in the management of the college. ${ }^{5}$ New York City's municipal colleges adopted the democratic form of government in 1938 . These three examples are typical of the trend.

The war apparently interrupted further reorganization in American colleges and universities for there have been no outstanding instances of college government reorganization since Pearl Harbor. However, as postwar problems become less complex, thought will no doubt turn once again toward shared faculty responsibility and faculty representation, for "faculty participation has become... a part of good college administration." 6

\footnotetext{
1 "Place and Function of Faculties in College and University Government: Committee Report and Sym. posium." American Association of University Professors. Bulletin 26:171-216, April r940.

2 Ibid, p.I75.

3 Ibid., p. 18 I.

- Blewett, E. Y. "New Type of Faculty Organization." Journal of Higher Education 9:201-06, April I 9.38 .

'Eikenberry, D. H. "Development and Operation of Democratic Administration." Educational Research Bulletin I $9: 449-56$, November 1940.
}

The adoption of a democratic form of college and university administration may have a profound affect upon the libraries of the institutions concerned. Under reorganization the library may be constituted as a full department of the college on the same basis as a department engaged in formal classroom teaching., Or reorganization may provide direct representation on executive committees, faculty council, etc., not only by the chief librarian, but by other members of the library staff, perhaps representing their respective ranks; the librarian and his staff may share responsibility equally with other departments in the administration of the college. If reorganization provides these rights and privileges, the library should have an unparalleled opportunity to develop, for this would mean that the library has been given full recognition. How libraries have fared under reorganized college administration is difficult to determine as almost nothing appears on the subject in professional literature. This fact suggests that libraries may not have fared too well. If the latter be the case, if college reorganization has by-passed the library, the lot of those libraries may indeed be hard. A conventional college or university library in a progressive institution which has adopted faculty managemcnt would be an anachronism. In such cases, immediate remedial measures should be initiated. A prospective administrative reorganization should take full cognizance of the potentialities of the library as an

"Grinnell, John E. "A Dean Looks at Democracy in College Goyernment." American Association of 
instructional department. The reason for this may be clarified below.

Reference has just been made to the public colleges of New York City. In 1938 the Board of Higher Education of the City of New York, with the approval of the faculties, established a democratic organization for faculty management and representation. Because of the advanced nature of the plan, the adoption of the new by-laws was a most important event, hailed at the time as a significant contribution to higher education. ${ }^{7}$ The very size of the institutions made the adoption of the new plan a notable achievement.

Apart from the validity of democratic college government, which is not here evaluated, the trend is a fact and one which college and university librarians cannot ignore for reasons given below. The reorganization of the colleges of New York City and its affect upon the libraries may be taken as a case in point. These college libraries were not by-passed; they were accorded a status enjoyed by few libraries. The whole library-faculty-college administration relationship was completely changed, and the libraries were given the opportunity to develop. To tell the story of the libraries in New York's colleges, it will be necessary to describe briefly the organization of higher education in New York City.

\section{Higher Education in New York City}

Education in New York State is a function of the state, and the state education law stipulates that in cities of over one million population there shall be a board of higher education. The Board of Higher Education of New York City consists of twenty-one citizens appointed by the mayor for a term of nine years. ${ }^{8}$ The board is

\footnotetext{
'Shukotoff, A. "Democracy in New York City Colleges." American Teacher v.23, pt. 1, February 1939, p. I $2-15$.

8 New York (City) Board of Higher Education. Laws and By-Laws Governing the Board of Higher Education, September 1938, Sect. I1 42 .
}

"subject to the visitation of the Regents of the University of the State of New York."9 New York City's Board of Higher Education administers four colleges with a total enrolment of 63,723 full- and part-time students, an aggregate faculty of nearly 3400 and an annual budget of $\$ 13,000,000$. The four colleges in the system are Brooklyn College; City College, this year celebrating its one hundredth anniversary; Hunter College, for women only, until the G.I.'s invasion; and Queens College, the youngest and the smallest of the four.

With the libraries of the colleges legally designated as instructional departments of the respective colleges, ${ }^{10}$ it logically follows that all ranks of librarians are members of the faculty. The librarian, associate and assistant librarians have had faculty status since the adoption of the by-laws but this was not true of the lowest ranking and largest group, that of library assistant. ${ }^{11}$ At last, the question of faculty status - of long concern to many other librarians-has been satisfactorily adjusted in New York's municipal colleges. The board of higher education has settled the question in no halfway manner. All librarians with tenure, including library assistants, are now full members of the faculty enjoying all rights and benefits thereof without restrictions or qualifications. ${ }^{12}$ In these public colleges there was possibly greater justification than elsewhere for including within the faculty all library ranks, for the college democratic system is based on faculty representation and any rank outside the faculty is deprived of the right of representation in the faculty or on executive committees. The recent ac-

\footnotetext{
Ibid., Sect. 1143 .

10 Ibid., Sect. ropf.

11 Estes, Rice. "Faculty Status in the City College Libraries." College and Research Libraries 3:43-45, December I94I. Of value historically; the conditions described have subsequently been rectified.

12 New York (City) Board of Higher Education. Proceedings, June 24, 1946, p. 196. Item 3. Amendment to the by-laws of the board of higher education to bestow faculty status on the rank of library assistant.
} 
tion of the board with respect to the largest professional group within the library adds a major note of progress to the subject of academic rank for librarians, on which a number of librarians have written. ${ }^{13}$

\section{Representation Affects Library}

The system of representation, one of the principal features of democratic college government, involves the library because the library is one of the departments of the college. (Consequently, any reference below to "college departments" includes the library department.) Departments in the city colleges have representation at the highest level through departmental chairmen. The highest executive body is the committee on faculty personnel and budget, which, for the sake of brevity, will hereafter be referred to as the personnel and budget committee. This committee corresponds to the senate in other institutions. The librarian, as chairman of the library department, represents the library on this committee. ${ }^{14}$ The composition and functions of the personnel and budget committee are pertinent because of the relation of this committee to the library. The committee is composed of the president, as chairman, the dean of the faculty and other deans, and the department chairmen. ${ }^{15}$ The personnel and budget committee has important duties. It considers the annual budget of the college and acts upon all recommenda-

${ }^{13}$ Bishop, William Warner. "The College Library and College Teaching." Association of American Col. leges. Bulletin 23:190-200, May I937.

Downs, Robert B. "Academic Status for University Librarians-a New Approach." College and Research Libraries 7:6-9, 26, January 1946.

Estes, Rice, op. cit.

McMillen, James A. "Academic Status of Library Staff Members of Large Universities." College and

Research Libraries $1: 138.40$, March 1940. brarians." A.L.A. Bulletin 33:232-33, 302, April I939. Marcus, R. Z. "The Meek Do Not Inherit the Earth." [letter to the editor] Wilson Library Bulletin

20:I90-91, November ${ }^{1945}$. Wriston, Henry M. College Librarian and the Teaching Staff." A.L.A. Bulletin 29:1 77-82, April

${ }_{14}^{1935}$ New York (City) Board of Higher Education.

Laws and By-Laws.... Sect. ro5a.

15 Ibid., Sect. 105 b. tions for appointments as submitted by the departments; it is concerned with reappointments, leaves of absence, and promotions. The committee recommends action to the president who must consider such recommendations in submitting his recommendations to the board of higher education. ${ }^{16}$ It is also concerned with the college budget. This is prepared by the president and submitted by him to the personnel and budget committee for its recommendations. ${ }^{17}$ The committee also receives and considers petitions and appeals from the instructional staff on matters relating to status and compensation and presents its recommendations to the president. Further provision is made for the protection of the staff member by means of appeals from a decision of the president which may be made by a member of the staff or any faculty committee through the president to the board of higher education. ${ }^{18}$ The committee meets at least once a month through the school year. Thus, the library, through its chairman, has an equal representation with all the other departments in the committee on faculty personnel and the budget.

Every rank within each department has representation on the faculty council by secret ballot by members of each rank. For example, in the library all those of the rank of assistant librarian vote for their representative to faculty council, and, similarly, with each other rank. The term of office is three years. ${ }^{19}$ Faculty council assumes all responsibilities of the faculty although the full faculty, by two-thirds vote at a special meeting, may reverse any specific vote of the faculty council. ${ }^{20}$ Faculty council elects a six-member committee on committees which appoints standing committees for the year.

$$
\begin{aligned}
& 16 \text { Ibid., Sect. I } 05 \text { b. } \\
& 17 \text { Ibid., Sect. I } 5 \text { c. } \\
& 18 \text { Ibid., Sect. I } 05 d \text {. } \\
& 10 \text { Ibid., Sect. I } 04 \text { a. } \\
& 20 \text { Ibid., Sect. I04b. }
\end{aligned}
$$




\section{Organization of the Faculty}

The faculty of each college consists of the president, deans, directors, professors, the registrar, the librarian, associate professors, assistant professors, associate librarians, assistant librarians, library assistants, and instructors who are members of the permanent staff. ${ }^{21}$ The executive officer of the department is the department chairman. ${ }^{22}$ He carries out its policies as well as those of the faculty. The librarian is the chairman of the library department. Every chairman has authority to initiate policy and action concerning departmental affairs, subject to the powers delegated by the by-laws to the staff of the department in regard to educational policy and to the appropriate departmental committees in the matter of promotions and appointments. The chairman represents the department before the faculty council, the faculty, and the board. He presides at meetings of his department and prepares the tentative department budget which is subject to approval by the department's committee on appointments. After approval, he transmits it to the president together with his own recommendations. ${ }^{23}$

\section{College Departments Have Authority}

Probably each department of the municipal college has more authority than departments in many other colleges and universities. The department has control of educational policies of the department through the vote of all its members of the faculty (those with tenure) or, if it so desires, of all other members (those without tenure). The department cooperates with related departments and with college agencies in general in the development of divisional or college-wide interests. ${ }^{24}$ An un-

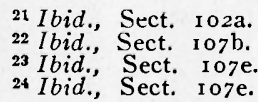

usual feature of the system is that chairmen may be elected by a department. The election must be approved by the president who may also appoint chairmen at his discretion. Election is by secret ballot by majority vote of all permanent members of the department for a term of three years. The chief librarian is an appointed officer. $\mathrm{He}$ is appointed by the president with the approval of the board. ${ }^{25}$

\section{Library Ranks and Qualifications}

In New York's public colleges the professional library staff consists of the librarian, associate librarians, assistant librarians, and library assistants. All members of the library staff with tenure are members of the faculty with representation as previously described.

Qualifications of library personnel, other than library assistants, are not specifically indicated in the by-laws. The qualifications of library assistants are not unusual : graduation from a recognized college and the completion of a one-year course of professional library training in a satisfactory library school. ${ }^{26} \mathrm{~A}$ further clause: "or, in lieu of such professional training, three years' experience in library work satisfactory to the librarian concerned and the president of the college," was deleted by action of the board in June 1946 , at the request of the library association and with the approval of the chief librarians of the four city colleges. Qualifications for librarians in other ranks are left to the determination of the librarian and the committee on appointments with the approval of the personnel and budget committee and the president.

\section{Promotions and Tenure}

A highly significant feature of the democratic organization in New York's colleges

25 Ibid., Sect. r о ге.

26 Ibid., Sect. 131, Schedule C14B, No. $\mathrm{C}_{4}$ 
is the machinery for promotions. Recommendations for promotion are made in the department by the department's elected committee on appointments and promotions. Recommendations are submitted together with any minority report to the committee on personnel and budget through the president. Provision for a minority report is a wise feature of the by-laws. The by-laws provide that the committee chairman (who is also the department chairman) should exercise executive authority where and when circumstances require such authority; for example, if the chairman disagrees with the other members of the department committee on appointments in the matter of an appointment or a promotion, the chairman may submit a minority report. This together with the majority report will be presented by the president to the personnel and budget committee for consideration and final action by majority vote.

All members of the permanent instructional staff have tenure. ${ }^{27}$ This includes all ranks of librarians who, as members of the faculty, have served at least three full years and have been appointed to a fourth full year. Persons appointed initially to the rank of professor, associate professor, or assistant professor may be placed on the permanent instructional staff (i.e., given tenure) by the board at its discretion after one year of satisfactory service. ${ }^{28}$

\section{Dual Roles Require Competent Staff}

It must be understood that the fact of having unusual rights and privileges does not in itself make a city college library, ipso facto, a good library. The democratic organization, within the framework of which the library's position is legally elevated, bestows upon the library potential opportunities for becoming unusually effective. Unless these potentialities be de-

\footnotetext{
27 Ibid., Sect. I I 43, c.3 (b).
}

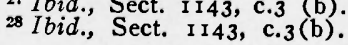

veloped, the library in the progressive democratic college will have poorer relations with the faculty than in the nondemocratic institution. The library will be an "instructional department" in name only and may be relegated to a position of minor importance.

The dual nature of the city college libraries requires a particularly competent staff if the libraries are to be good libraries and, at the same time, effective in college administration. Librarians must be wellqualified and positions must be attractive to retain the staff.

The effectiveness of the library in fulfilling its dual roles is assured in several ways:

r. By making careful initial appointments and reducing turnover. Extreme care must be exercised in making new appointments. The fixed salary schedule, regular annual increments, tenure, membership in and representation on the faculty, good working conditions, reasonable working hours, generous vacation allowance, sick leave and "special purpose" leave with pay, are humane, decent, and attractive features of New York's municipal college libraries. Personnel turnover is very small.

2. By making carefully considered recommendations for tenure. Judgment must be exercised in recommending tenure. Once a member of the library staff has tenure, he is, for all practical purposes, on the staff to stay. As the committee on rersonnel and budget is likely to follow the recommendation handed up by the departmental appointments committee, the latter must make sound recommendations.

3. By organization and administration. Efficient organization and good administration is essential. The library administration must examine and re-examine its organization with a view to increasing its opportunities for service and toward improving its administrative machinery.

4. By the cooperation of an informed staff. If the cooperation of the library staff is essential, it is axiomatic that it be well-informed. Minutes of the committee on personnel and budget and faculty council are available tc all members of the library and other depart- 
ment staffs. The librarian informs the library department's division heads, at the next scheduled meeting, of important action taken by the personnel and budget committee. Division meetings follow at which all staff members are informed of important action. Faculty council action is reported to the library staff at large by the library representatives in council.

5. By establishing definite policies and positive aims. Policies must be established and adhered to. Aims must be specific. Administrative decisions must be wise and positive. All must be in sympathy with the fact that the library is an instructional department with executive responsibilities.

\section{Library-Faculty Relations}

The library-faculty relationship is recognized as important in all college and university libraries. So fundamental is this relationship that it is not an overstatement to say that the effectiveness of the library is contingent upon it. If this is true in the conventional library in the institution without a democratic form of government, it is now probably obvious that good relations with the faculty in the reorganized institution is completely essential. However, this relationship is one that can only be developed gradually over a period of years. Every activity of the library must contribute to building the library's reputation. The conventional library need consider this only in terms of good library service. The library in the reorganized college must be mindful of its dual roles and think, too, in terms of the library staff's contribution to executive and special committees on which the members serve. It should also be remembered that the relationship is a two-way affair: not only library-faculty but facultylibrary. The librarian may have to stimulate the latter, but there must be active cooperation of the faculty with the library.

Following are a number of illustrations by which the two-way relationship between library and faculty may be established, de- veloped, and maintained. These suggestions are given as recommended practice although it is fully realized that many librarians and faculties follow such a program.

One link of the chain of library-faculty relations is the conventional faculty library committee. In the city colleges it is customary for the faculty council's committee on committees to appoint a faculty library committee. (The librarians, through their representatives in faculty council, participated in the election of the committee on committees which appointed the library committee.) The fact that the librarian is a member ex officio of the library committee is the only unusual feature of an otherwise common practice. The library committee acts in an advisory capacity. At the beginning of each term it reviews the allotments of the book fund made by the librarian to each department and may then recommend changes in the allotment on the basis of special knowledge of curricula requirements.

In the matter of book selection, it is good practice to encourage the faculty to recommend titles for purchase. It is extremely helpful for the library to have a large group of experts aiding in this important activity.

Each department of the city college elects (or the chairman appoints) a departmental committee on library affairs, one member of which is designated as the department's representative to the library. ${ }^{29}$ The department library committee receives book recommendations from its faculty and screens the titles before they are forwarded to the library. The department representative to the library provides liaison between the department and the librarian. The existence of the department library committee and the department representative does not discourage close contact between the library

29 The program for library-faculty cooperation is not consistently uniform practice in all the city colleges. The practices described are in operation at Brooklyn College. 
and individual members of each department. There is no legal requirement for the existence of a library committee, for the department library committees, or for the department representative to the library. This is college policy, established for practical purposes-as a matter of good sense. This is true of all statements regarding faculty-library relationships hereafter described.

The library is related to other college departments in other ways. In the matter of departmental book ordering, departments needing books of their own, initiate the orders but route all such orders to the library for checking. This prevents unnecessary duplication among the departments and provides an opportunity for factual verification of the orders. All book deliveries are made to the library, where the books are recorded, entered in the card catalog, and forwarded to the department which ordered them. The library maintains a central union catalog of all books and periodicals elsewhere on the campus. It has supervisory jurisdiction over films and recordings, in fact, over all audio-visual material. A plan to centralize all audiovisual material in the library is now under consideration.

Library publications also foster desirable library-faculty relations. The faculty is informed of recent acquisitions in a monthly list which includes the titles of all books received and cataloged during the previous month; new periodicals added, with a descriptive note regarding the scope of the periodical; new pamphlets and documents of significance. $^{30}$ A recently added feature is a section of short book reviews of important titles appearing in the list. The reviews are written by members of the library staff and by subject specialists among the faculty at

\footnotetext{
30 Brooklyn College. Library. Technical Services Division. "Recent Accessions and Library News." (Mimeo.)
}

large. Because of a growing interest in audio-visual teaching aids and because audio-visual film and equipment will be centered in the library, the publication will include a bibliography of pertinent articles on teaching aids, a list of new films, etc., available and of those received. Another section, entitled "Library News," contains library information of general interest to the faculty.

New members of the faculty are invited to come to the library to meet the librarian and to discuss library matters. They are also sent a handbook" as a "guide to the services available and an explanation of practices and procedures" in the library.

\section{Summary}

From the foregoing, it is clear that the library has a place in the college, designated by law. The individual library staff member as well as the department is part of the college. The unusual rights and privileges enjoyed impose administrative responsibilities on the library staff; on the chief librarian, representing the department in the top executive committee and elsewhere; on the library representatives in faculty council ; on the elected departmental committee on appointments. The ultimate effectiveness of the college very largely depends on how authority is executed and on how the responsibility is shouldered in the departments. But the library in the municipal college cannot rest upon its legal rights and privileges. It must take an active professional part in college affairs. Apart from its activity and interest in college management, it must maintain a high level of professional library service. This is distinctly a dual role. And the library ${ }^{32}$ has a substantial professional obligation in a college with 16,000 students and a faculty

\footnotetext{
${ }^{81}$ Brooklyn College. Library. Library Handbook for the Faculty.
} 
of 839 exclusive of extension and adult education divisions.

Most college and university libraries are called on to render traditional library service and nothing more. Few are concerned with appointments and promotions throughout the college, few are interested in educational policy, curriculum changes, or in the college budget, except as it affects the library. The value of the library's participation in college management might be debated, but it is believed that librarians who actively participate in administrative affairs inevitably develop perspective, acquire an understanding of college problems, and have an appreciation of its educational aims that make them better able to help and work with students and faculty.

The dual role of the New York municipal college library rather obviously requires a staff of unusual ability to succeed as a traditional library and be effective in its college-wide administrative role.

Thus, the college library has ceased to be just a service organization, for it is an instructional department of the college, sharing with all other departments responsibilty for college administration, the librarians being represented on all governing bodies. While qualifications for librarians are not unusual, appointments and promotions are because they are made in democratic fashion.
The staff is encouraged by regular increments in salary and protected by tenure under the educational laws of the state. The status of the library is also established by law, but the professional standing and effectiveness of the library is a matter the librarian and his staff must determine, for the library cannot rest on its legal rights and still be a good library. Its excellence as a library depends on the individual staff members and on the internal organization that is developed in the library. ${ }^{33}$ To be fully effective, the library must maintain close relations with the faculty.

A library that is so much a part of the college should be the very center around which the whole college revolves. The library must be the dominant department. Library literature has frequently voiced this sentiment but too often, it is feared, in the vein of wishful thinking. It is believed that the board of higher education with its enlightened by-laws gives the college library opportunities which many librarians have long dreamed of but seldom realized. Here, in New York's municipal colleges, is the opportunity to fulfil those dreams. The library is ready for unparalleled professional growth.

${ }^{3}$ Smith, M. H., and Kenny, M. I. "The Technical Services Department at Brooklyn College Library." ( $T o$ appear in a forthcoming issue of College and $R e$ search Libraries as an illustration of staff reorganiza. tion.) 